\title{
Scaffolds with a standardized macro-architecture fabricated from several calcium phosphate ceramics using an indirect rapid prototyping technique
}

\author{
C. E. Wilson - C. A. van Blitterswijk • \\ A. J. Verbout · W. J. A. Dhert · J. D. de Bruijn
}

Received: 15 November 2009/Accepted: 25 October 2010/Published online: 11 November 2010

(C) The Author(s) 2010. This article is published with open access at Springerlink.com

\begin{abstract}
Calcium phosphate ceramics, commonly applied as bone graft substitutes, are a natural choice of scaffolding material for bone tissue engineering. Evidence shows that the chemical composition, macroporosity and microporosity of these ceramics influences their behavior as bone graft substitutes and bone tissue engineering scaffolds but little has been done to optimize these parameters. One method of optimization is to place focus on a particular parameter by normalizing the influence, as much as possible, of confounding parameters. This is difficult to accomplish with traditional fabrication techniques. In this study we describe a design based rapid prototyping method of manufacturing scaffolds with virtually identical macroporous architectures from different calcium phosphate ceramic compositions. Beta-tricalcium phosphate, hydroxyapatite (at two sintering temperatures) and biphasic calcium phosphate scaffolds were manufactured. The
\end{abstract}

C. E. Wilson · A. J. Verbout · W. J. A. Dhert $(\bowtie)$

Division of Surgical Specialties, Department of Orthopaedics,

University Medical Center Utrecht, G05.228, PO Box 85500,

3508 GA Utrecht, The Netherlands

e-mail: w.dhert@umcutrecht.nl

J. D. de Bruijn

School of Engineering and Materials Science, Queen Mary

University of London, Mile End Road, London E1 4NS, UK

C. A. van Blitterswijk

Department of Tissue Regeneration, Institute for Biomedical

Technology, University of Twente, PO Box 217, 7500 AE

Enschede, The Netherlands

W. J. A. Dhert

Faculty of Veterinary Medicine, Utrecht University,

Yalelaan 1, 3584 CL Utrecht, The Netherlands macro- and micro-architectures of the scaffolds were characterized as well as the influence of the manufacturing method on the chemistries of the calcium phosphate compositions. The structural characteristics of the resulting scaffolds were remarkably similar. The manufacturing process had little influence on the composition of the materials except for the consistent but small addition of, or increase in, a beta-tricalcium phosphate phase. Among other applications, scaffolds produced by the method described provide a means of examining the influence of different calcium phosphate compositions while confidently excluding the influence of the macroporous structure of the scaffolds.

\section{Introduction}

Calcium phosphate ceramics have seen extensive clinical application as synthetic bone fillers and graft extenders [1-3]. The biocompatibility as well as osteoconductive and osteoinductive properties of these ceramics have been well documented [4-12]. Bone Tissue Engineering research has capitalized on these qualities, making porous calcium phosphate ceramics a popular choice of scaffold [13-16].

Porous ceramics for medical applications have been manufactured for decades using a variety of traditional methods. Conversion of natural structures, such as coral $[17,18]$, and trabecular bone $[19,20]$ yield porous ceramics with organic architectures that appear very similar to that of the bone that is being replaced. Synthetic manufacturing methods such as foaming [21-23], dualphase mixing [24] and the slip-casting of polymer foams and particles [25-27], may also be used to produce porous ceramics. However, conversion and synthetic techniques 
result in highly complex macroporous structures that are difficult to define quantitatively. Despite the complex nature of the porous ceramics produced by conventional means, quite some information is available regarding the influence the porous structure has on osteoconduction [2835], BMP induced osteogenesis [26, 36-38], and osteoinduction $[11,39]$.

Rapid prototyping (RP), also termed free form fabrication, refers to a variety of technologies capable of producing three-dimensional (3D) physical constructs directly from 3D computer aided models. In recent years, rapid prototyping has been proposed for the production of both scaffolds with controlled porous architectures [40-42] as well as porous implants with patient specific geometries [43-45]. Several rapid prototyping techniques have been developed to produce ceramic scaffolds for bone tissue engineering research [46-49].

The aim of the current study was to produce porous ceramic scaffolds from different calcium phosphate materials with sufficiently similar macroporous architectures as to be able to reasonably eliminate the macroporous architecture as a confounding variable in future tissue engineering studies. The scaffolds were produced by casting four different calcium phosphate materials into identical molds produced using a rapid prototyping technique. The resulting macroporous structures as well as the chemistry before and after manufacture were evaluated.

\section{Materials and methods}

\subsection{Scaffold design and mold fabrication}

Scaffolds were designed and molds fabricated as described previously [49]. Briefly, the scaffolds specifications called for an interconnecting network of $400 \mu \mathrm{m}$ square crosssection channels oriented along the orthogonal axes and separated from each other and the exterior by $400 \mu \mathrm{m}$. Six, four, and three channels were incorporated in the $\mathrm{X}, \mathrm{Y}$, and $\mathrm{Z}$ axis directions, resulting in overall design dimensions of $5.2 \times 3.6 \times 2.8 \mathrm{~mm}$, respectively. A schematic of such a scaffold is shown in Fig. 1. Molds, with cavities for the production of six scaffolds each, were designed using the Rhinoceros ${ }^{\circledR}$ computer aided design software (Robert McNeel \& Associates, USA). The mold model was scaled to account for shrinkage of approximately $20 \%$ during thermal processing demonstrated previously by our hydroxyapatite ceramics. This resulted in pre-thermal processing scaffold dimensions of $6.5 \times 4.5 \times 3.5 \mathrm{~mm}$ in the $\mathrm{X}, \mathrm{Y}$, and $\mathrm{Z}$ axis directions. Multiple copies of the mold were produced using a ModelMaker II rapid prototyping system (Solidscape Inc., USA).

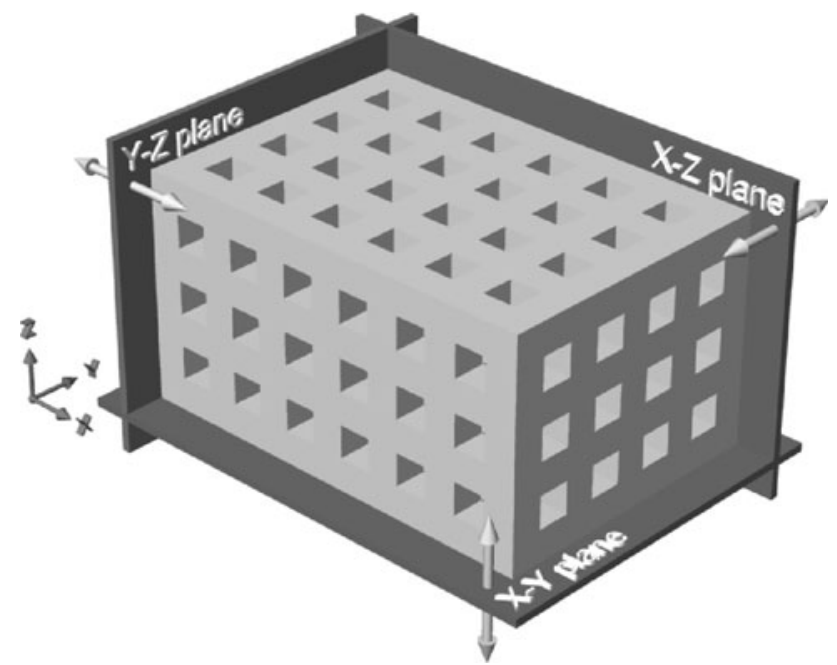

Fig. 1 Schematic of the designed scaffolds including the three orthogonal planes used to define the scaffold surfaces

\subsection{Ceramic slurries}

Ceramic scaffolds were manufactured to achieve four conditions through combinations of calcium phosphate ceramic compositions and sintering temperatures as outlined in Table 1. Hydroxyapatite powder (HA, Merck, Germany), beta-tricalcium phosphate powder (TCP, Merck, Germany) and biphasic calcium phosphate powder (BCP, wt\% 85/15 HA/TCP, IsoTis SA) were obtained commercially. The HA and TCP raw powders were calcined by heating from ambient to $900^{\circ} \mathrm{C}$ at a rate of $100^{\circ} \mathrm{C} /$ hour and then cooled naturally with no dwell period. Aqueous slurries of HA, TCP, and BCP powders were prepared as previously described for the production of cast plates [50]. In brief, the slurry components detailed below were slowly admixed until a homogenous blend was achieved. The HA and TCP slurries consisted of $67.1 \mathrm{wt} \%$ calcined HA powder, $28.6 \mathrm{wt} \%$ demineralized water, 2.6 wt $\%$ ammonia solution (25\%, Merck), $1.5 \mathrm{wt} \%$ deflocculant (Dolapix, Aschimmer \& Schwarz GmbH, Germany). Once a homogeneous blend was obtained, a CMC binder was added (0.15 wt $\%$, Pomosin BV, The Netherlands) to the HA slurry and the slurry further mixed until homogeneous. The BCP slurry consisted of $56.4 \mathrm{wt} \%$ ceramic powder, $37.6 \mathrm{wt} \%$ demineralized water, $3.9 \mathrm{wt} \%$ ammonia solution, and $2.1 \mathrm{wt} \%$ deflocculant. No binder was added to the TCP and BCP slurries. All slurries were stored in covered beakers until there use within the same day.

\subsection{Scaffold fabrication}

The molds were filled using a simple vacuum device [49]. Millex ${ }^{\circledR}-$ GV filter units (25 mm, Millipore S.A., France) were divided in half and the filter paper removed to expose 
Table 1 Scaffold dimensions, shrinkage, volume, weight, and apparent porosity of scaffolds compared to the solids in slurry and sintering temperature during manufacturing

\begin{tabular}{|c|c|c|c|c|c|c|c|}
\hline Material & $\begin{array}{l}\text { Solids in } \\
\text { slurry (wt\%) }\end{array}$ & $\begin{array}{l}\text { Sintering } \\
\text { temp. }\left({ }^{\circ} \mathrm{C}\right)\end{array}$ & $\begin{array}{l}\text { Exterior dimensions } \\
(\mathrm{mm} \pm \mathrm{SD})\end{array}$ & $\begin{array}{l}\text { Srinkage (from } \\
\text { 'as molded', \%) }\end{array}$ & $\begin{array}{l}\text { Volume } \\
\left(\mathrm{mm}^{3} \pm \mathrm{SD}\right)\end{array}$ & $\begin{array}{l}\text { Weight } \\
(\mathrm{mg} \pm \mathrm{SD})\end{array}$ & $\begin{array}{l}\text { Apparent porosity } \\
(\% \pm \text { SD) }\end{array}$ \\
\hline $\mathrm{HA} \mathrm{h}$ & 67.1 & 1250 & $\begin{array}{l}\mathrm{x}: 5.05 \pm 0.05 \\
\mathrm{y}: 3.48 \pm 0.03 \\
\mathrm{z}: 2.73 \pm 0.03\end{array}$ & $\begin{array}{l}\mathrm{x}: 22.35 \\
\mathrm{y}: 22.68\end{array}$ & $47.92 \pm 0.87$ & $76.16 \pm 2.89$ & $49.65 \pm 1.76$ \\
\hline HA 1 & 67.1 & 1150 & $\begin{array}{l}x: 6.14 \pm 0.05 \\
y: 4.23 \pm 0.13 \\
z: 3.26 \pm 0.11\end{array}$ & $\begin{array}{l}x: 5.48 \\
y: 6.04\end{array}$ & $84.63 \pm 3.17$ & $73.82 \pm 5.40$ & $72.39 \pm 1.27$ \\
\hline BCP & 56.4 & 1150 & $\begin{array}{l}\mathrm{x}: 5.45 \pm 0.05 \\
\mathrm{y}: 3.73 \pm 0.06 \\
\mathrm{z}: 2.90 \pm 0.06\end{array}$ & $\begin{array}{l}\mathrm{x}: 16.21 \\
\mathrm{y}: 7.86\end{array}$ & $58.96 \pm 1.38$ & $48.86 \pm 2.33$ & $73.72 \pm 1.03$ \\
\hline TCP & 67.1 & 1150 & $\begin{array}{l}x: 6.05 \pm 0.04 \\
y: 4.15 \pm 0.13 \\
z: 3.21 \pm 0.09\end{array}$ & $\begin{array}{l}x: 6.88 \\
y: 7.86\end{array}$ & $80.53 \pm 3.05$ & $69.49 \pm 4.54$ & $72.54 \pm 1.10$ \\
\hline
\end{tabular}

the perforated interior surface. The open face of a mold was carefully placed against the interior surface of a filter half and secured by circumferentially wrapping with wax laboratory film. The mold/filter constructs were attached to $50 \mathrm{ml}$ syringes and flushed with demineralized water. During casting, the beakers containing slurry were placed on a Porex vibrating table (Renfert, Germany). This assisted in mold filling by imparting shear energy and thus lowering the viscosity of the pseudoplastic (shear thinning) slurries. The molds were filled by submerging the open face of each mold in slurry and then drawing vacuum pressure using the syringe. The molds were then placed on a sheet wax laboratory film and the syringes and filter halves removed. The molds were allowed to air dry overnight at room temperature and were then further dried for $24 \mathrm{~h}$ at $50^{\circ} \mathrm{C}$ in air. Excess slurry from each ceramic composition was processed identically to the molded ceramics to serve as controls when examining material chemistry and to further examine the previously observed influence of the rapid prototyping wax on the material composition [49].

Debinding and sintering of the ceramics were performed in two steps in a high temperature furnace (Nabertherm 1400, Germany). Debinding of all ceramics was performed by heating at a rate of $0.5^{\circ} \mathrm{C} /$ minute to $400^{\circ} \mathrm{C}$ and then cooling naturally with no dwell period. The ceramics were then sintered using a $600 \mathrm{~min}$ heating phase with a $480 \mathrm{~min}$ dwell period at the final sintering temperature followed by natural cooling. One set of HA scaffold was sintered at $1250^{\circ} \mathrm{C}$, designate $\mathrm{HA} \mathrm{h}$, while a sintering temperature of $1150^{\circ} \mathrm{C}$ was used for a second set of HA scaffolds, designate HA 1, as well as all of the TCP and BCP scaffolds. Excess ceramic, occasionally present on the scaffold faces corresponding to the open sides of the molds, was removed using a rotary polisher (LaboPol-5, Struers,
Denmark) with 1200 grit waterproof silicon carbide paper (Struers). The ceramics were cleaned by ultrasound for 15 min each in acetone, $100 \%$ ethanol and deionized water, and then dried in air at $50^{\circ} \mathrm{C}$.

\subsection{Scaffold characterization}

The exterior scaffold dimensions were measured using a digital caliper (CD-15C, Mitutoyo Ltd., UK) and used to calculate the shrinkage resulting from the combined debinding and sintering processes. Scanning electron microscopy (SEM, XL 30 ESEM-FEG, Philips, The Netherlands) was used to examine the macro-architecture and surface micro-structure of the scaffolds. The dimensions of the macroporosity were measured in each of the orthogonal planes (Fig. 1). The apparent porosity of the scaffolds was determined by comparing the apparent density of each scaffold (dry weight/measured volume) and the theoretical density of HA $\left(3.156 \mathrm{~g} / \mathrm{cm}^{3}\right)$ [39], TCP $(3.14 \mathrm{~g} / \mathrm{cm} 3)$, and BCP (85\% HA, $15 \%$ TCP). The chemistry of raw ceramic powder, calcined ceramic powder, non-molded sintered ceramic and molded scaffolds were evaluated by X-ray diffraction (XRD, Miniflex, Rigaku, Japan). Finally, the potential contamination of the ceramics by residues from the wax mold material was investigated by performing energydispersive X-ray spectroscopy (EDX, XL 30 ESEM-FEG, Philips, The Netherlands) on the surface of cast and non-cast (not exposed to wax mold material) ceramics specimens.

\section{Results}

The manufacturing process resulted in scaffolds with remarkably similar structural appearances (Fig. 2). Scaffold dimensions, shrinkage, volume, weight and apparent 
Fig. 2 The four ceramic compositions all in 25 well plates. Note the similarity of the scaffold structures and the differences in the scaffold colors

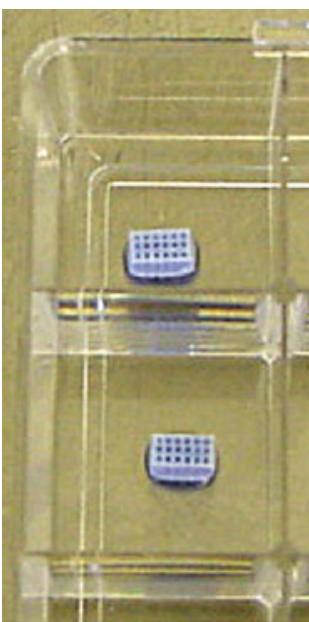

$\mathrm{HA} \mathrm{h}$

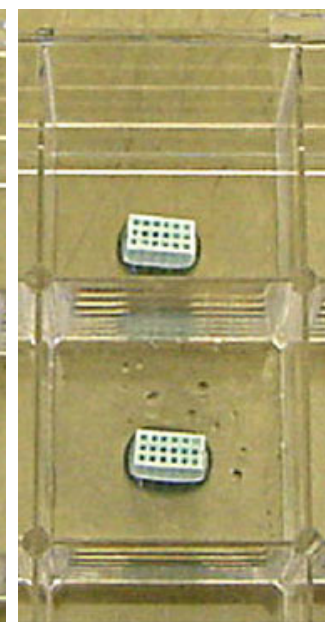

HA I

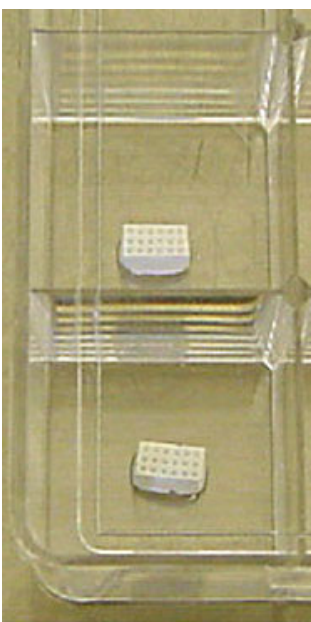

$\mathrm{BCP}$

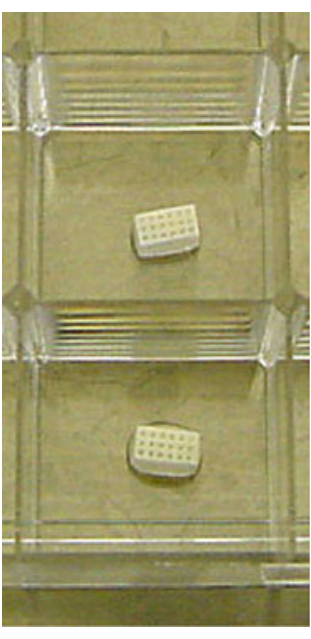

TCP
Table 2 Pore dimensions by orthogonal plane (Fig. 1)

\begin{tabular}{llll}
\hline Material & \multicolumn{3}{l}{ Pore dimensions $(\mu \mathrm{m} \pm \mathrm{SD})$} \\
\cline { 2 - 4 } & x-y plane & x-z plane & y-z plane \\
\hline HA h & x: $286 \pm 15$ & x: $353 \pm 28$ & y: $394 \pm 24$ \\
& y: $280 \pm 16$ & z: $339 \pm 17$ & z: $376 \pm 30$ \\
HA 1 & x: $414 \pm 44$ & x: $470 \pm 37$ & y: $484 \pm 29$ \\
& y: $416 \pm 34$ & z: $496 \pm 21$ & z: $486 \pm 27$ \\
BCP & x: $366 \pm 24$ & x: $444 \pm 47$ & y: $432 \pm 37$ \\
& y: $377 \pm 18$ & z: $433 \pm 20$ & z: $414 \pm 42$ \\
TCP & x: $405 \pm 43$ & x: $460 \pm 36$ & y: $474 \pm 29$ \\
& y: $408 \pm 33$ & z: $486 \pm 21$ & z: $476 \pm 26$ \\
\hline
\end{tabular}

porosity values are summarized in Table 1 . The high sintering temperature HA scaffolds exhibited the greatest shrinkage and lowest apparent porosity. The BCP scaffolds also demonstrated considerable shrinkage but maintained a high apparent porosity similar to the low sintering temperature HA and TCP scaffolds. The low sintering temperature HA and TCP scaffolds exhibited the lowest shrinkage. Shrinkage in the $\mathrm{z}$-direction and volumetric shrinkage were not calculated since the respective surfaces were manually polished to remove excess ceramic and therefore do not represent the 'as cast' properties. In order to evaluate whether the various treatments influenced the ratio of macroporosity to total porosity, computer models of the porous scaffolds were created using the measured exterior and macropore dimensions in Tables 1 and 2, respectively. These computer models were used to calculate the approximate volume of the macroporosity. Table 3 shows the volumes approximated by the computer models for the various treatments and compares the resulting macroporosity to the measured apparent porosity.

SEM images of the resulting scaffolds are shown in Fig. 3. These scaffolds are discussed in the following text using the axes and orthogonal planes depicted in Fig. 1. A distinctive texture of parallel ridges and valleys was observed in SEM micrographs on all vertical scaffold surfaces, i.e., surfaces parallel to the $\mathrm{x}-\mathrm{z}$ and $\mathrm{y}-\mathrm{z}$ planes. This texture is an impression of the rapid prototyped mold and a consequence of the layer-by-layer manufacturing of the mold. The cross-sectional geometry of the channels was dependant upon the orientation of the channel. Channels running in the $\mathrm{x}$ - and $\mathrm{y}$-directions were square in cross section with textured vertical surfaces and smooth horizontal surfaces. Channels running in the z-direction were rounded with no apparent texturing. Again, this is a consequence of the mold manufacturing process.

The surface microporosity of the scaffolds, as observed by SEM, varied with material composition and sintering temperature (Fig. 3). The BCP scaffolds exhibited a

Table 3 Scaffold volumes and macroporosity calculated form computer models compared to the measured total apparent porosity and other porosity (difference between macro and apparent porosity)

\begin{tabular}{lllllll}
\hline Material & $\begin{array}{l}\text { Total } \\
\text { volume }\left(\mathrm{mm}^{3}\right)\end{array}$ & $\begin{array}{l}\text { Material } \\
\text { volume }\left(\mathrm{mm}^{3}\right)\end{array}$ & $\begin{array}{l}\text { Pole } \\
\text { volume }\left(\mathrm{mm}^{3}\right)\end{array}$ & $\begin{array}{l}\text { Macro- } \\
\text { porosity }(\%)\end{array}$ & $\begin{array}{l}\text { Apparent } \\
\text { porosity }(\%)\end{array}$ & $\begin{array}{l}\text { Other } \\
\text { porosity }(\%)\end{array}$ \\
\hline HA h & 47.98 & 31.78 & 16.19 & 33.75 & 49.65 & 15.90 \\
HA 1 & 84.67 & 50.19 & 34.48 & 40.72 & 72.39 & 31.67 \\
BCP & 58.95 & 34.82 & 24.14 & 40.94 & 73.72 & 32.78 \\
TCP & 80.60 & 48.08 & 32.51 & 40.34 & 72.54 & 32.20 \\
\hline
\end{tabular}



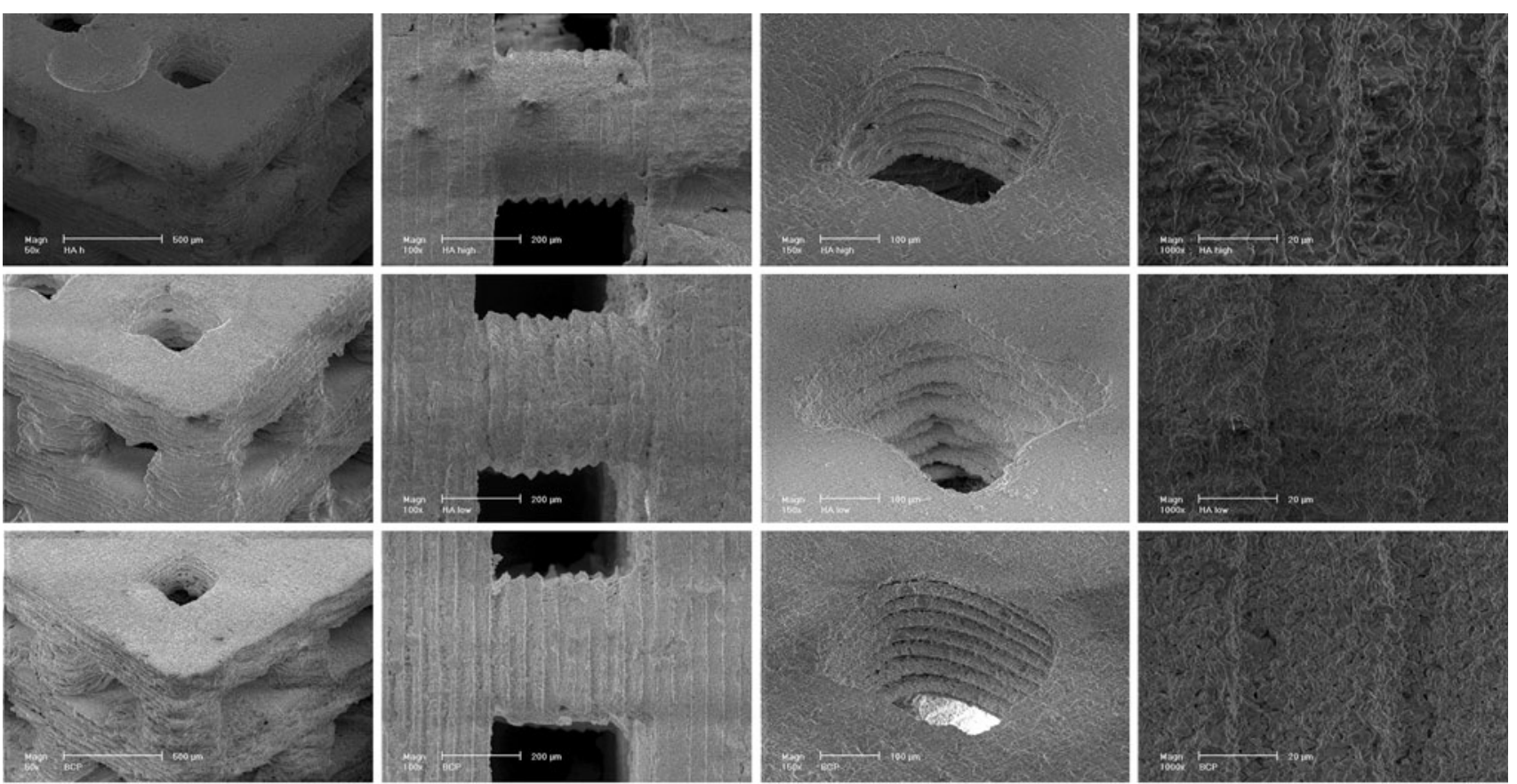
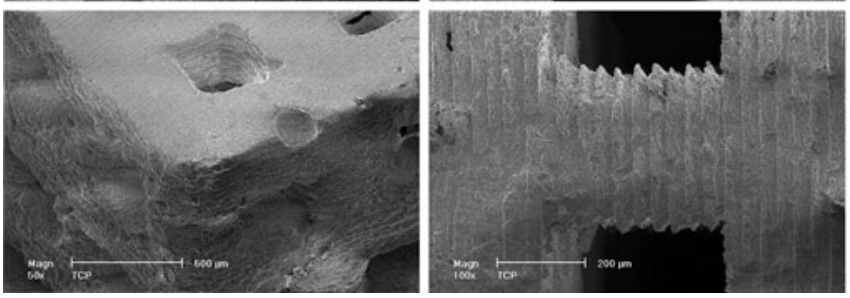

Fig. 3 SEM micrographs of the four scaffold materials. Rows top to bottom HA h, HA 1, BCP, and TCP. First column Perspective view of scaffolds at $50 \times$ magnification (bar $50 \mu \mathrm{m})$. Second column Scaffold structures at $100 \times$ magnification $($ bar $200 \mu \mathrm{m}$ ). Note the regular

spectrum of surface microporosity features from approximately 1 to $10 \mu \mathrm{m}$ in size. The surface features of the low sintering temperature HA scaffolds were similar to the BCP with perhaps somewhat less and smaller surface microporosity, approximately $0.5-5 \mu \mathrm{m}$. The high sintering temperature HA scaffolds exhibited smoother surfaces with very little microporosity. The TCP material, in contrast to the other materials sintered at low temperatures, appeared very similar to the high sintering temperature HA with very little surface microporosity.

The XRD patterns for the different ceramic chemistries, shown in Fig. 4, were generally as expected. Figure 4a shows the patterns for the HA ceramic raw powder, calcined powder, non-molded material sintered at $1150^{\circ} \mathrm{C}$, scaffolds sintered at $1150^{\circ} \mathrm{C}$, non-molded material sintered at $1250^{\circ} \mathrm{C}$, and scaffolds sintered at $1150^{\circ} \mathrm{C}$. Several peaks associated with TCP formation were observed in the patterns for the cast HA scaffold materials at both the 1150 and $1250^{\circ} \mathrm{C}$ sintering temperatures (vertical lines in Fig. 4a). The BCP ceramics also demonstrated these TCP peaks in the cast scaffolds (Fig. $4 \mathrm{~b}$, vertical lines). The

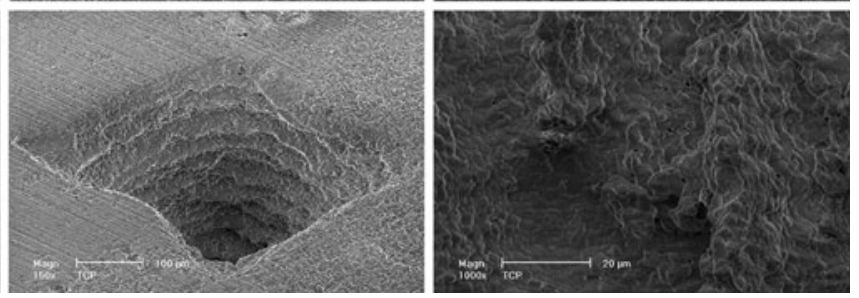

surface texture on the scaffolds. Third column Scaffold pores at $150 \times$ magnification (bar $200 \mu \mathrm{m}$ ). Fourth column Scaffold surfaces at $1000 \times$ magnification (bar $20 \mu \mathrm{m}$ )

TCP ceramics exhibited changes, relative to the raw powder, that were consistent with the calcination and sintering process temperatures (Fig. 4c). The XRD patterns for the four scaffold conditions are shown in Fig. 5 for clarity. EDX of the surfaces of both cast and non-cast ceramic specimens showed identical spectra consistent with the calcium phosphate materials. There was no evidence of contamination from the wax mold material.

\section{Discussion and conclusions}

The present study demonstrates the application of Computer Aided Design and Rapid Prototyping technologies for the production of ceramic scaffolds from different chemistries but with defined, virtually identical, macroarchitectures. Other than producing macroporosities with pore dimension in the range suggested in the literature for

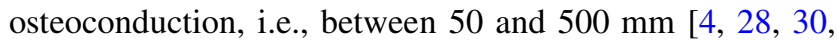
$31,34]$, we did not attempt to produce optimal or ideal porous structures. The purpose of this study was to 
Fig. 4 XRD patterns of a HA $h$ (1250) and HA 1 (1150), b BCP, and $\mathbf{c}$ TCP. Shown are XRD patterns of the raw powder, calcined powder and molded ceramics (scaffolds). XRD patterns of non-molded ceramics are also shown in (a) for the HA h (1250) and HA 1 (1150) materials. Vertical dotted lines indicate additional peaks associated with beta-TCP formation that are only present in the molded specimens (scaffolds)
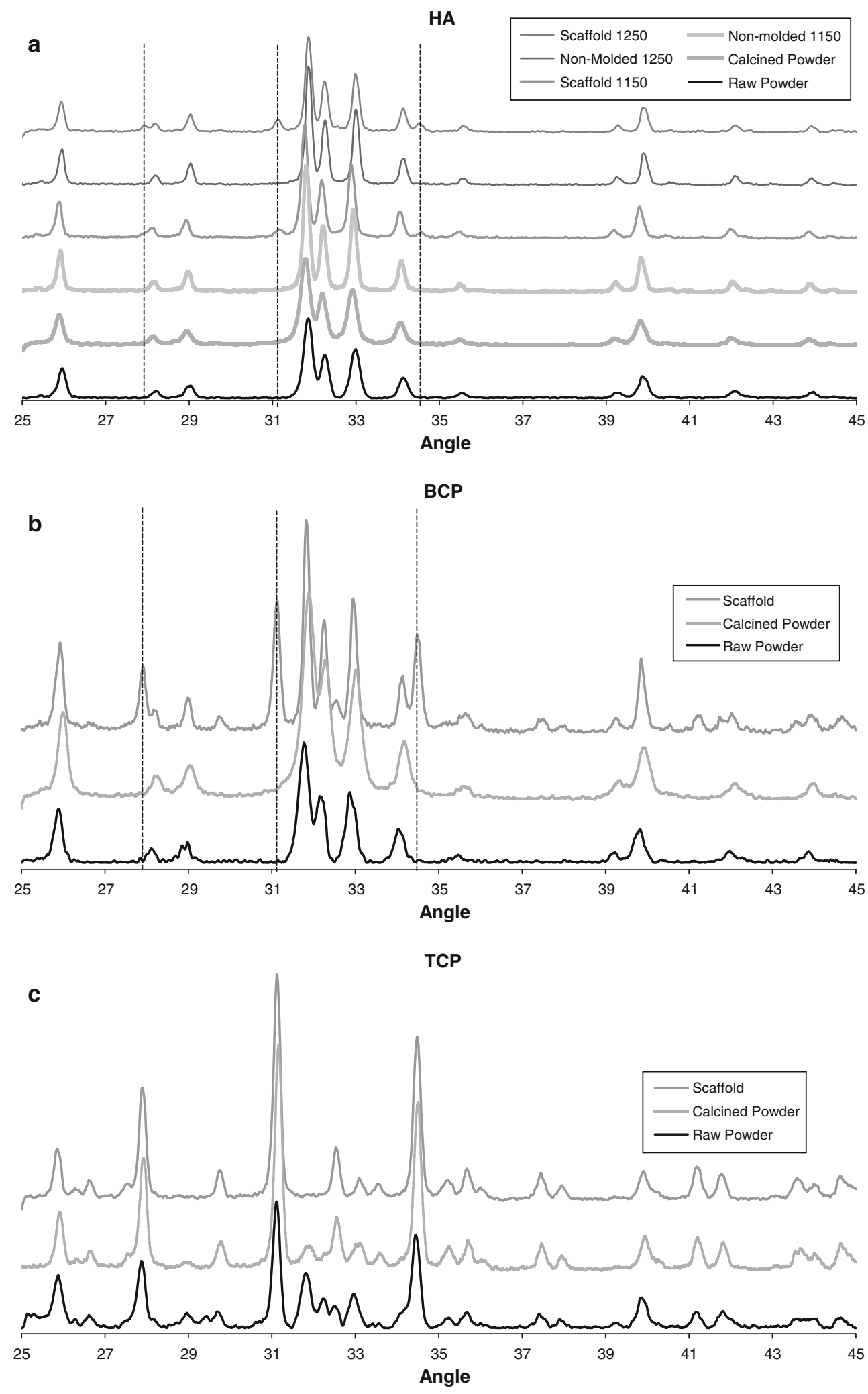

manufacture porous scaffolds in which the macroporous architecture was designed and sufficiently similar to be able to reasonable exclude the macroporous architecture as a confounding variable in future research studies. The material chemistries and thermal processing methods employed in this study were chosen to provide continuity with materials used in past and ongoing research [49-54]. 
Fig. 5 XRD patterns of the four scaffold materials. Vertical dotted lines indicate beta-TCP peaks which form in the HA and $\mathrm{BCP}$ material as a result of the molding process

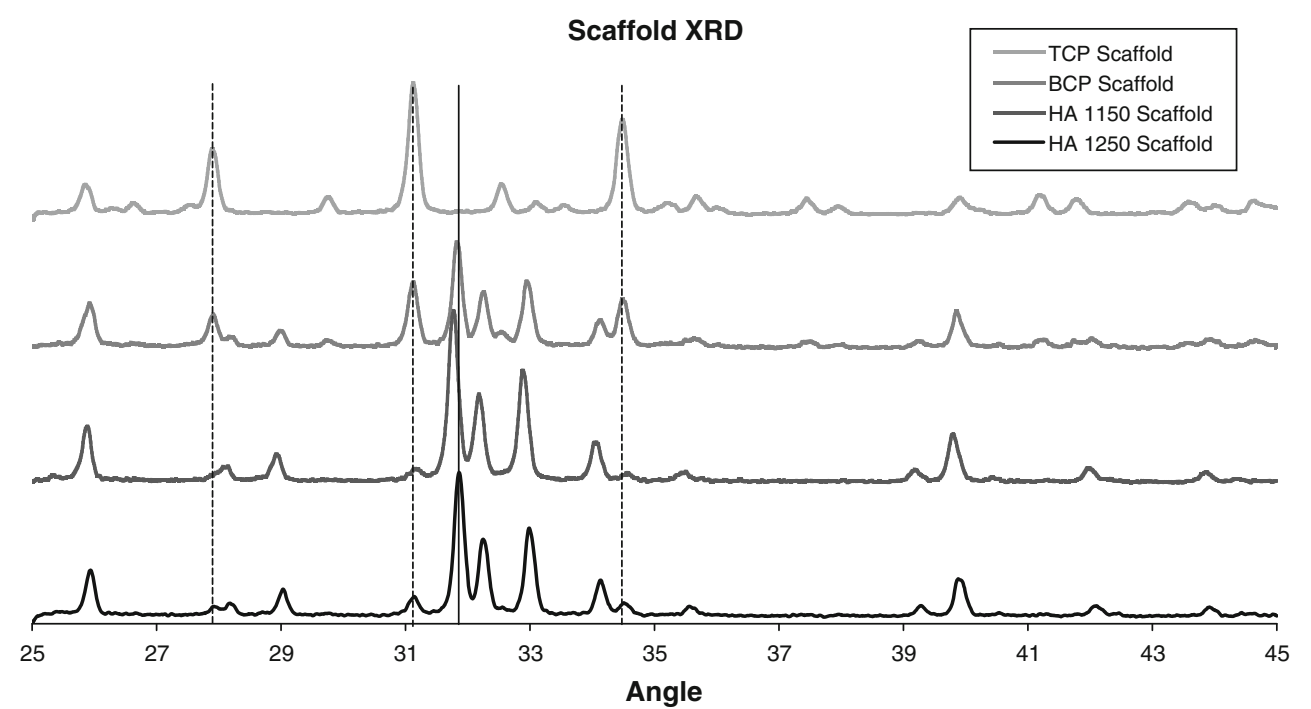

Although the visual appearance of the scaffolds was similar with regard to structure, there were differences in shrinkage and therefore the macroporous dimensions. As expected from our previous work, a sintering temperature of $1250^{\circ} \mathrm{C}$ resulted in a shrinkage of just over $22 \%$ for the HA material compared to approximately $6 \%$ shrinkage for HA and TCP sintered at $1150^{\circ} \mathrm{C}$. The relatively large shrinkage of $16-17 \%$ for the BCP scaffolds, also sintered at $1150^{\circ} \mathrm{C}$, can almost completely be accounted for by the lower solids loading of the BCP slurry (56.4 wt\%) compared to the HA and TCT slurries (67.1 wt\%). The lower solids loading was necessary to achieve appropriate rheological properties for the casting of scaffolds from slurries of the non-calcined $\mathrm{BCP}$ powder. Interestingly, the apparent porosity of BCP scaffolds was very similar to the TCP and low sintering temperature HA scaffolds despite the much higher shrinkage (Table 2). Comparing the porosity resulting from the measured macroporous structure to the total apparent porosity, Table 3 , reveals that the a much greater proportion of the apparent porosity of the high sintering temperature HA is likely due to the macroporosity compared to the lower sintering temperature materials. This indicated greater densification due to the higher sintering temperature. The BCP, TCP and low sintering temperature HA all had similar proportions of macroporosity despite the much higher shrinkage of the BCP material.

The texture exhibited on the vertical surfaces of the scaffold (Fig. 1), as well as the rounded nature of the macropores in the $\mathrm{z}$-direction, are a consequence of the rapid prototyping technique used to manufacture the molds. This technique jets molten droplets of wax material, which flatten and spread when they strike the surface, to build each layer of the molds. As molds are built up vertically layer by layer, this results in a texture on the vertical surfaces ( $\mathrm{x}-\mathrm{z}$ and $\mathrm{y}-\mathrm{z}$ planes) which is subsequently cast into the ceramic. The rounded corners of channels running in the $\mathrm{z}$-direction (cross-sections parallel to the $\mathrm{x}-\mathrm{y}$ plane) result from the coalescing or pooling of adjacent droplets prior to solidification, resulting in rounding of both inside and outside corners within the printed layers. These rounded mold corners are then cast into the resulting ceramic scaffolds and observed in channels running parallel to the z-direction.

Compositional analyses by XRD were largely as expected. The XRD patterns for the HA and BCP scaffolds indicated that a TCP phase had been introduced. Since the XRD patterns of the non-molded specimens did not show the TCP phase and the molded and non-molded materials were treated identically with the exception of the molding process, it is likely that the presence of TCP phase after molding results from the exposure of the $\mathrm{HA}$ and $\mathrm{BCP}$ materials to the wax mold material itself, despite elemental analysis of cast and non-cast specimens demonstrated there was no direct contamination of the ceramics by the mold material. The mechanism for this is not clear but is consistent with our previous findings for HA materials [49].

In conclusion, we have demonstrated a rapid prototyping method for fabricating ceramic scaffolds with virtually identical, 3-dimensional, macroporous architectures from different calcium phosphate ceramics. Scaffolds produced by this method will not only enhance research aimed at optimizing macroporous architectures and material compositions but will improve many other aspects of tissue engineering research by eliminate differences in macroporous structure as a confounding variable.

Acknowledgments The authors would like to thank The Netherlands Technology Foundation for financial support (Grant UGN.4966). We also thank Ellen van Leeuwen (Technical University of Eindhoven) and Dr. ShiHong Li (IsoTis N.V.) for their assistance. 
Open Access This article is distributed under the terms of the Creative Commons Attribution Noncommercial License which permits any noncommercial use, distribution, and reproduction in any medium, provided the original author(s) and source are credited.

\section{References}

1. Bucholz RW. Nonallograft osteoconductive bone graft substitutes. Clin Orthop Relat Res. 2002;395(395):44-52.

2. Burger EL, Patel V. Calcium phosphates as bone graft extenders. Orthopedics. 2007;30(11):939-42.

3. Moore WR, Graves SE, Bain GI. Synthetic bone graft substitutes. ANZ J Surg. 2001;71(6):354-61.

4. Chang BS, Lee CK, Hong KS, Youn HJ, Ryu HS, Chung SS, et al. Osteoconduction at porous hydroxyapatite with various pore configurations. Biomaterials. 2000;21(12):1291-8.

5. de Groot K. Bioceramics consisting of calcium phosphate salts. Biomaterials. 1980;1(1):47-50.

6. Gauthier O, Bouler JM, Aguado E, Pilet P, Daculsi G. Macroporous biphasic calcium phosphate ceramics: influence of macropore diameter and macroporosity percentage on bone ingrowth. Biomaterials. 1998;19(1-3):133-9.

7. Holmes RE. Osteoconduction in hydroxyapatite-based materials. In: Brighton CT, Friedlaender G, Lane JM, editors. Bone formation and repair. Rosemont: American Academy of Orthopedic Surgeons; 1994. p. 355-65.

8. Ripamonti U. Osteoinduction in porous hydroxyapatite implanted in heterotopic sites of different animal models. Biomaterials. 1996;17(1):31-5.

9. Yuan H, de Bruijn JD, Zhang X, van Blitterswijk CA, de Groot $\mathrm{K}$. Bone induction by porous glass ceramic made from Bioglass (45S5). J Biomed Mater Res. 2001;58(3):270-6.

10. Yuan H, Kurashina K, de Bruijn JD, Li Y, de Groot K, Zhang X. A preliminary study on osteoinduction of two kinds of calcium phosphate ceramics. Biomaterials. 1999;20(19):1799-806.

11. Habibovic P, Gbureck U, Doillon CJ, Bassett DC, van Blitterswijk CA, Barralet JE. Osteoconduction and osteoinduction of low-temperature 3D printed bioceramic implants. Biomaterials. 2008;29(7):944-53.

12. Habibovic P, Kruyt MC, Juhl MV, Clyens S, Martinetti R, Dolcini $\mathrm{L}$, et al. Comparative in vivo study of six hydroxyapatitebased bone graft substitutes. J Orthop Res. 2008;26(10):1363-70.

13. Anselme K, Noel B, Flautre B, Blary MC, Delecourt C, Descamps $\mathrm{M}$, et al. Association of porous hydroxyapatite and bone marrow cells for bone regeneration. Bone. 1999;25(2 Suppl):51S-4S.

14. de Bruijn JD, van den Brink I, Mendes S, Dekker R, Bovell YP, van Blitterswijk CA. Bone induction by implants coated with cultured osteogenic bone marrow cells. Adv Dent Res. 1999; $13: 74-81$.

15. Goshima J, Goldberg VM, Caplan AI. The osteogenic potential of culture-expanded rat marrow mesenchymal cells assayed in vivo in calcium phosphate ceramic blocks. Clin Orthop Relat Res. 1991;262:298-311.

16. Ohgushi H, Okumura M, Tamai S, Shors EC, Caplan AI. Marrow cell induced osteogenesis in porous hydroxyapatite and tricalcium phosphate: a comparative histomorphometric study of ectopic bone formation. J Biomed Mater Res. 1990;24(12):1563-70.

17. Roy DM, Linnehan SK. Hydroxyapatite formed from coral skeletal carbonate by hydrothermal exchange. Nature. 1974; 247(438):220-2.

18. White RA, Weber JN, White EW. Replamineform: a new process for preparing porous ceramic, metal, and polymer prosthetic materials. Science. 1972;176(37):922-4.
19. Lin FH, Liao CJ, Chen KS, Sun JS, Lin CY. Preparation of betaTCP/HAP biphasic ceramics with natural bone structure by heating bovine cancellous bone with the addition of (NH(4))(2)HPO(4). J Biomed Mater Res. 2000;51(2):157-63.

20. Tancred DC, McCormack BA, Carr AJ. A synthetic bone implant macroscopically identical to cancellous bone. Biomaterials. 1998;19(24):2303-11.

21. Rejda BV, Peelen JG, de Groot K. Tri-calcium phosphate as a bone substitute. J Bioeng. 1977;1(2):93-7.

22. Sepulveda P, Binner JG, Rogero SO, Higa OZ, Bressiani JC. Production of porous hydroxyapatite by the gel-casting of foams and cytotoxic evaluation. J Biomed Mater Res. 2000;50(1): $27-34$.

23. Tamai N, Myoui A, Tomita T, Nakase T, Tanaka J, Ochi T, et al. Novel hydroxyapatite ceramics with an interconnective porous structure exhibit superior osteoconduction in vivo. J Biomed Mater Res. 2002;59(1):110-7.

24. Li SH, De Wijn JR, Layrolle P, De Groot K. Synthesis of macroporous hydroxyapatite scaffolds for bone tissue engineering. J Biomed Mater Res. 2002;61(1):109-20.

25. Bouler JM, Trecant M, Delecrin J, Royer J, Passuti N, Daculsi G. Macroporous biphasic calcium phosphate ceramics: influence of five synthesis parameters on compressive strength. J Biomed Mater Res. 1996;32(4):603-9.

26. Tsuruga E, Takita H, Itoh H, Wakisaka Y, Kuboki Y. Pore size of porous hydroxyapatite as the cell-substratum controls BMPinduced osteogenesis. J Biochem (Tokyo). 1997;121(2):317-24.

27. Woyansky JS, Scott CE, Minnear WP. Processing of porous ceramics. Am Ceram Soc Bull. 1992;71:1674-82.

28. Bloebaum RD, Bachus KN, Momberger NG, Hofmann AA. Mineral apposition rates of human cancellous bone at the interface of porous coated implants. J Biomed Mater Res. 1994;28(5): 537-44.

29. Eggli PS, Muller W, Schenk RK. Porous hydroxyapatite and tricalcium phosphate cylinders with two different pore size ranges implanted in the cancellous bone of rabbits. A comparative histomorphometric and histologic study of bony ingrowth and implant substitution. Clin Orthop Relat Res. 1988;232:127-38.

30. Hofmann AA, Bloebaum RD, Bachus KN. Progression of human bone ingrowth into porous-coated implants. Rate of bone ingrowth in humans. Acta Orthop Scand. 1997;68(2):161-6.

31. Hulbert SF, Young FA, Mathews RS, Klawitter JJ, Talbert CD, Stelling FH. Potential of ceramic materials as permanently implantable skeletal prostheses. J Biomed Mater Res. 1970;4(3): 433-56.

32. Karageorgiou V, Kaplan D. Porosity of 3D biomaterial scaffolds and osteogenesis. Biomaterials. 2005;26:5474-91.

33. Kuhne JH, Bartl R, Frisch B, Hammer C, Jansson V, Zimmer M. Bone formation in coralline hydroxyapatite. Effects of pore size studied in rabbits. Acta Orthop Scand. 1994;65(3):246-52.

34. Schliephake H, Neukam FW, Klosa D. Influence of pore dimensions on bone ingrowth into porous hydroxylapatite blocks used as bone graft substitutes. A histometric study. Int J Oral Maxillofac Surg. 1991;20(1):53-8.

35. Hing KA, Best SM, Tanner KE, Bonfield W, Revell PA. Mediation of bone ingrowth in porous hydroxyapatite bone graft substitutes. J Biomed Mater Res A. 2004;68(1):187-200.

36. Jin QM, Takita H, Kohgo T, Atsumi K, Itoh H, Kuboki Y. Effects of geometry of hydroxyapatite as a cell substratum in BMPinduced ectopic bone formation. J Biomed Mater Res. 2000; 52(4):491-9.

37. Kuboki Y, Takita H, Kobayashi D, Tsuruga E, Inoue M, Murata $\mathrm{M}$, et al. BMP-induced osteogenesis on the surface of hydroxyapatite with geometrically feasible and nonfeasible structures: topology of osteogenesis. J Biomed Mater Res. 1998;39(2): 190-9. 
38. Ripamonti U, Ma S, Reddi AH. The critical role of geometry of porous hydroxyapatite delivery system in induction of bone by osteogenin, a bone morphogenetic protein. Matrix. 1992;12(3): 202-12.

39. Habibovic P, de Groot K. Osteoinductive biomaterials-properties and relevance in bone repair. J Tissue Eng Regen Med. 2007;1(1):25-32.

40. Hutmacher DW. Scaffold design and fabrication technologies for engineering tissues-state of the art and future perspectives. J Biomater Sci Polym Ed. 2001;12(1):107-24.

41. Yang S, Leong KF, Du Z, Chua CK. The design of scaffolds for use in tissue engineering. Part II. Rapid prototyping techniques. Tissue Eng. 2002;8(1):1-11.

42. Hollister SJ. Porous scaffold design for tissue engineering. Nat Mater. 2005;4(7):518-24.

43. Chim H, Schantz JT. New frontiers in calvarial reconstruction: integrating computer-assisted design and tissue engineering in cranioplasty. Plast Reconstr Surg. 2005;116(6):1726-41.

44. Chu TM, Orton DG, Hollister SJ, Feinberg SE, Halloran JW. Mechanical and in vivo performance of hydroxyapatite implants with controlled architectures. Biomaterials. 2002;23(5):1283-93.

45. Levy RA, Chu TM, Halloran JW, Feinberg SE, Hollister S. CT-generated porous hydroxyapatite orbital floor prosthesis as a prototype bioimplant. AJNR Am J Neuroradiol. 1997;18(8): $1522-5$.

46. Chu TM, Halloran JW, Hollister SJ, Feinberg SE. Hydroxyapatite implants with designed internal architecture. J Mater Sci Mater Med. 2001;12(6):471-8.

47. Dutta Roy T, Simon JL, Ricci JL, Rekow ED, Thompson VP, Parsons JR. Performance of hydroxyapatite bone repair scaffolds created via three-dimensional fabrication techniques. J Biomed Mater Res A. 2003;67(4):1228-37.
48. Seitz H, Rieder W, Irsen S, Leukers B, Tille C. Three-dimensional printing of porous ceramic scaffolds for bone tissue engineering. J Biomed Mater Res B Appl Biomater. 2005;74(2): $782-8$.

49. Wilson CE, de Bruijn JD, van Blitterswijk CA, Verbout AJ, Dhert WJ. Design and fabrication of standardized hydroxyapatite scaffolds with a defined macro-architecture by rapid prototyping for bone-tissue-engineering research. J Biomed Mater Res. 2004;68A(1):123-32.

50. Wilson CE, Kruyt MC, de Bruijn JD, van Blitterswijk CA, Oner $\mathrm{FC}$, Verbout AJ, et al. A new in vivo screening model for posterior spinal bone formation: comparison of ten calcium phosphate ceramic material treatments. Biomaterials. 2006;27(3): 302-14.

51. Geuze RE, Kruyt MC, Verbout AJ, Alblas J, Dhert WJ. Comparing various off-the-shelf methods for bone tissue engineering in a large-animal ectopic implantation model: bone marrow, allogeneic bone marrow stromal cells, and platelet gel. Tissue Eng Part A. 2008;14(8):1435-43.

52. Kruyt M, de Bruijn J, Rouwkema J, van Blitterswijk C, Oner C, Verbout A, et al. Analysis of the dynamics of bone formation, effect of cell seeding density, and potential of allogeneic cells in cell-based bone tissue engineering in goats. Tissue Eng Part A. 2008;14(6):1081-8.

53. Kruyt MC, Dhert WJ, Oner FC, van Blitterswijk CA, Verbout AJ, de Bruijn JD. Analysis of ectopic and orthotopic bone formation in cell-based tissue-engineered constructs in goats. Biomaterials. 2007;28(10):1798-805.

54. Kruyt MC, Wilson CE, de Bruijn JD, van Blitterswijk CA, Oner $\mathrm{CF}$, Verbout AJ, et al. The effect of cell-based bone tissue engineering in a goat transverse process model. Biomaterials. 2006;27(29):5099-106. 